\title{
Badania porównawcze napawanych plazmowo warstw niklowych z węglikami Ti i Cr
}

\author{
Plasma surfaced nickel layers with chromium \\ and titanium carbides - comparative research
}

\section{Streszczenie}

W artykule przedstawiono wyniki badań struktury kompozytowych powłok na osnowie stopu NiSi2B z dodatkiem węglików $\mathrm{Ti}$ i $\mathrm{Cr}$, napawanych plazmowo z mieszaniny proszków na podłoża ze stali niskostopowej. Określono udział i rozmieszczenie fazy umacniającej w osnowie. Wykazano, iż odmienny charakter oddziaływania węglików $\mathrm{Ti}$ i $\mathrm{Cr}$ z ciekłym stopem Ni wpływa istotnie na proces formowania się napoin kompozytowych oraz na rozmieszczenie i udział cząstek fazy umacniającej w matrycy.

\section{Abstract}

The results of structure investigation of composite layers based on NiSi2B alloy with $\mathrm{Cr}$ and $\mathrm{Ti}$ carbides dopands are presented in the article. The layers were previously deposited by plasma powder transferred arc weIding method onto low alloy steel substrates. The content and distribution of strengthening phase particles in the layer's matrix were determined. It was proved that formation of composite overlays along with refractory particles distribution are significantly affected by $\mathrm{Ti}$ and $\mathrm{Cr}$ carbides interaction of different character with liquid nickel alloy.

\section{Wstęp}

Napawanie plazmowe proszkowe PPTAW (Plasma Powder Transferred Arc Welding) należy do ważnych spawalniczych metod stosowanych w modyfikacji i regeneracji powierzchni części maszyn. W metodzie tej łuk plazmowy charakteryzuje się dużą koncentracją energii i wysoką temperaturą, co zapewnia nanoszenie powłoki z dużą prędkością przy stosunkowo niewielkim nadtopieniu materiału rodzimego, a krótki czas oddziaływania strumienia energii nie powoduje nadmiernych zmian w strefie wpływu ciepła podłoża $[1 \div 3]$. Do ważnych cech tej metody należy zaliczyć również możliwość otrzymywania napoin o różnym składzie chemicznym, w tym warstw o strukturze kompozytowej. Napoiny kompozytowe łączą w sobie właściwości odpornej na ścieranie i jednocześnie stosunkowo plastycznej osnowy oraz twardej ceramiki. Powłoki

Dr inż. Mariusz Bober, prof. dr hab. inż. Jacek Senkara - Politechnika Warszawska. kompozytowe otrzymywane są na ogół z proszków technikami napawania plazmowego, laserowego, przetapiania wiązką elektronów bądź natryskiwania termicznego $[4,5]$. Powłoki kompozytowe uzyskane przez natryskiwanie nie mogą przenosić dużego obciążenia ściernego z powodu mechanicznego charakteru połączenia warstwy z materiałem podłoża oraz porowatości obecnej w tych warstwach. W warunkach eksploatacyjnych znacznie lepsze właściwości wykazują powłoki napawane, które są metalurgicznie związane z materiałem podłoża. Wykorzystanie do napawania warstw kompozytowych wysokoenergetycznych wiązek, tj. elektronowej i laserowej, może powodować rozpuszczanie twardych cząstek fazy umacniającej, co prowadzi do obniżenia właściwości tych powłok. Ponadto znaczny koszt urządzeń ogranicza przemysłowe zastosowanie napawania laserowego i wiązką elektronów. W związku z tym napawanie plazmowe proszkowe jest najczęściej stosowaną techniką otrzymywania powłok kompozytowych $[1,4,6 \div 10]$.

Materiał osnowy stanowią $z$ reguły stopy na bazie niklu, a uzyskane napoiny mają gładkie lico, wysoką twardość i dobrą odporność na zużycie ścierne 


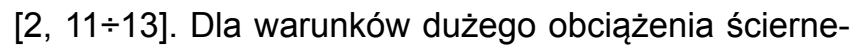
go właściwości tych powłok są podwyższane przez dodatek do osnowy cząstek fazy umacniającej, często w postaci węglików metali IVB-VIB grup układu okresowego pierwiastków, $z$ uwagi na ich właściwości [14].

Na proces formowania się powłok kompozytowych oraz rozmieszczenie i udział cząstek fazy umacniającej w osnowie ma wpływ wiele czynników, a fundamentalnym z nich jest rodzaj i intensywność oddziaływania materiału cząstek z ciekłą osnową, którego miarą jest ich zwilżalność. Jeśli cząstki fazy umacniającej są dobrze zwilżalne ciekłą osnową, są wówczas zatrzymywane $w$ ciekłym jeziorku, napoiny formują się poprawnie, a rozmieszczenie cząstek jest zbliżone do równomiernego. Gdy cząstki fazy umacniającej nie są bądź są słabo zwilżalne ciekłą osnową, następuje ich wypieranie z ciekłego jeziorka i nierównomierne rozmieszczenie, zwykle tylko w okolicy lica warstwy. Niedostateczna zwilżalność cząstek umocnienia cieczą metaliczną jest również przyczyną powstawania różnych niezgodności spawalniczych.

Dobra zwilżalność występuje dla układów osnowa - umocnienie charakteryzujących się występowaniem tego samego rodzaju wiązania chemicznego. $Z$ analizy literatury wynika, że węgliki metali przejściowych IVB VIB grupy układu okresowego pierwiastków mają wiązania mieszane, w których obok metalicznego występuje udział wiązań kowalentnych, a nawet jonowych, przy czym nie ma zgodności poglądów w kwestii ich ewentualnych udziałów $[15,16]$.

W artykule przedstawiono wyniki badań modelowych oddziaływania cieczy metalicznej - stopu $\mathrm{Ni}$ - z węglikami Ti i Cr w zestawieniu z analizą struktury $w$ realnych napoinach kompozytowych $z$ udziałem tych węglików.

\section{Przygotowanie próbek, materiały i urządzenia}

Badania modelowe obejmowały przeprowadzenie testów rozpływności stopu na bazie Ni na podłożach z węglików Ti i Cr. Komercyjnie węgliki te występuja w postaci proszków, natomiast do wymienionych badań niezbędne były lite, płaskie makroskopowe podłoża. Opracowano specjalną metodę wykonania warstw z węglików $\mathrm{Ti}$ i $\mathrm{Cr}$ na neutralnym podłożu. $\mathrm{Na}$ odpowiednio przygotowaną powierzchnię szlifowanych płytek Mo zostały naniesione powłoki węglików Ti i Cr metodą magnetronową. Kawałki materiału $\mathrm{w}$ formie cylindrów o jednakowych wymiarach i składzie podanym poniżej, odpowiadającym osnowie powłok kompozytowych do testów rozpływności, uzyskano wykonując wytop w indukcyjnym piecu próżniowym z czystych składników. Testy rozpływności wykonano przy zastosowaniu specjalnego urządzenia zaprojektowanego i wykonanego w Zakładzie Inżynierii Spajania Politechniki Warszawskiej. Pole rozpływu ciekłego stopu Ni na
Tablica I. Stałe parametry napawania plazmowego

Table. I. Constant parameters of plasma surfacing

\begin{tabular}{|l|c|}
\hline \multicolumn{1}{|c|}{ Parametr } & Wartość \\
\hline Natężenie prądu łuku wewnętrznego & $40 \mathrm{~A}$ \\
\hline Napięcie łuku plazmowego & $25 \mathrm{~V}$ \\
\hline Wydatek proszku & $6 \mathrm{~g} / \mathrm{min}$ \\
\hline Prędkość napawania & $50 \mathrm{~mm} / \mathrm{min}$ \\
\hline Wydatek gazu (argon): & \\
plazmotwórczego & $1,5 \mathrm{I} / \mathrm{min}$ \\
osłonowego & $8 \mathrm{I} / \mathrm{min}$ \\
transportującego & $5 \mathrm{I} / \mathrm{min}$ \\
\hline Amplituda oscylacji & $8 \mathrm{~mm}$ \\
\hline Prędkość ruchu oscylacyjnego & $450 \mathrm{~mm} / \mathrm{min}$ \\
\hline Odległość plazmotronu od przedmiotu napawanego & $15 \mathrm{~mm}$ \\
\hline Średnica dyszy zwężającej & $4 \mathrm{~mm}$ \\
\hline
\end{tabular}

podłożach węglikowych określano za pomocą programu do analizy obrazów metalograficznych AnalySIS.

$W$ ramach badań aplikacyjnych wykonano kompozytowe powłoki zawierające TiC lub $\mathrm{Cr}_{3} \mathrm{C}_{2}$ na podłożach ze stali niskostopowej S355J0. Powłoki te uzyskano przez napawanie plazmowe odpowiednich mieszanin proszków. Osnowę mieszanin stanowił proszek na bazie niklu firmy Deloro Stellite $\mathrm{GmbH}$ o symbolu DA 22. Według atestu producenta skład tego proszku był następujący: $0,03 \% \mathrm{C}, 2,4 \% \mathrm{Si}, 1,4 \% \mathrm{~B}$ oraz $0,4 \%$ $\mathrm{Fe}, \mathrm{Ni}$ - reszta. Ziarnistość zawiera się w przedziale $50 \div 150 \mu \mathrm{m}$. Proszek osnowy mieszano z proszkami węglika tytanu lub węglika chromu o tej samej ziarnistości w stosunku objętościowym 60:40.

Proces napawania plazmowego prowadzono przy pomocy urządzenia PTA 301 Control M firmy Hettiger Stellite. Próby napawania wykonano dla zakresu natężenia prądu łuku głównego $60 \div 120 \mathrm{~A}$. Pozostałe parametry procesu, ustalone na podstawie wcześniejszych badań, były stałe, przedstawiono je w tablicy I. Proces prowadzono bez podgrzewania wstępnego, a długość wszystkich ściegów wynosiła $60 \mathrm{~mm}$.

Otrzymane próbki poddano badaniom makroskopowym i mikroskopowym. Badania makroskopowe polegały na obserwacji okiem nieuzbrojonym i przy niewielkim powiększeniu. Próbki do badań mikroskopowych, dla zapewnienia poprawności wnioskowania, pobrano z jednakowej odległości $20 \mathrm{~mm}$ od początku ściegu. $Z$ uwagi na znaczną twardość powłok, cięcie materiału było wykonywane za pomoca wycinarki elektroerozyjnej. Zgłady metalograficzne przygotowano wg standardowej procedury w płaszczyźnie prostopadłej do osi napoiny. Do określenia rozmieszczenia i udziału fazy umacniającej zaadaptowano komputerowy program do analizy obrazów metalograficznych MultiScanBase.

\section{Wyniki badań}

Testy rozpływności stopu Ni na podłożach z węglików Ti i Cr prowadzono w atmosferze argonu o czystości 99,999\%. Wykonano po dwie serie doświadczeń dla każdego układu węglik-osnowa, podnosząc 

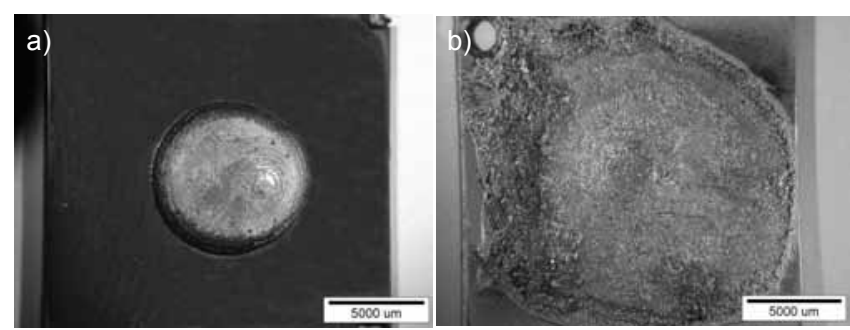

Rys. 1. Kropla stopu Ni na podłożu z węglika po teście rozpływności: a) $\mathrm{TiC}$, b) $\mathrm{Cr}_{3} \mathrm{C}_{2}$

Fig. 1. Liquid droplet of nickel alloy over carbide substrate after the spreading test: a) $\mathrm{TiC}, \mathrm{b}) \mathrm{Cr}_{3} \mathrm{C}_{2}$

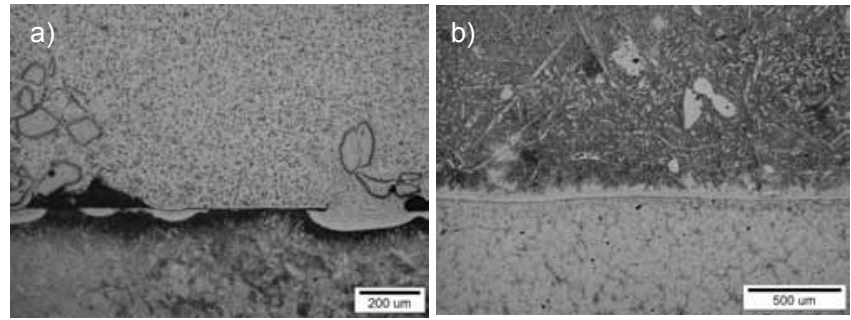

Rys. 2. Granica międzyfazowa podłoże - powłoka: a) widoczne przyklejenia powłoki umacnianej TiC $(\mathrm{I}=80 \mathrm{~A})$, b) ciągła linia wtopienia powłoki umacnianej $\mathrm{Cr}_{3} \mathrm{C}_{2}(\mathrm{I}=60 \mathrm{~A})$

Fig. 2. Substrate - overlay interface: a) incomplete wetting in the sample with $\mathrm{TiC}$ strengthening $(\mathrm{I}=80 \mathrm{~A})$; b) continuous fusion line in case of $\mathrm{Cr}_{3} \mathrm{C}_{2}$ strengthening $(\mathrm{I}=60 \mathrm{~A})$

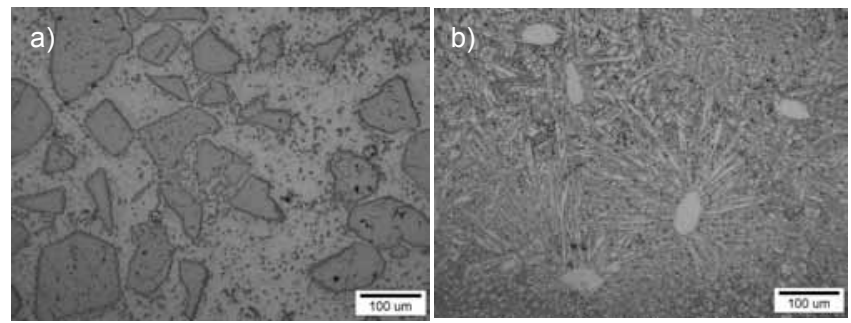

Rys. 3. Morfologia fazy umacniającej osnowę napoin z: a) $\mathrm{TiC}$ b) $\mathrm{Cr}_{3} \mathrm{C}_{2}$

Fig. 3. Strengthening phase particles' shapes and distributions: a) $\mathrm{TiC}$, b) $\mathrm{Cr}_{3} \mathrm{C}_{2}$

Tablica II. Pole powierzchni zajęte przez krople stopu Ni na podłożach węglikowych

Table II. Surface area of carbide substrate wetted by nickel alloy droplet

\begin{tabular}{|l|c|c|}
\hline \multicolumn{1}{|c|}{ Rodzaj podłoża } & $\mathrm{TiC}$ & $\mathrm{Cr}_{3} \mathrm{C}_{2}$ \\
\hline Pole powierzchni, $\mathrm{mm}^{2}$ & 48,9 & 249,5 \\
\hline${\text { Temperatura zakończenia procesu, }{ }^{\circ} \mathrm{C}}$ & 1350 & 1310 \\
\hline
\end{tabular}
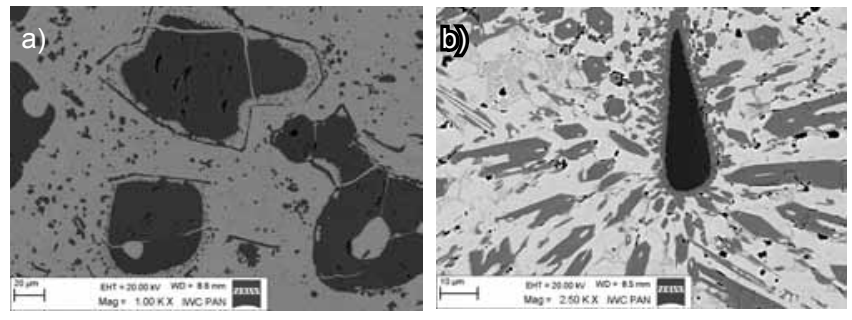

Rys. 4. Mikrostruktura kompozytowej powłoki o osnowie stopu $\mathrm{Ni}$ umacnianej węglikami: a) $\mathrm{TiC}$, b) $\mathrm{Cr}_{3} \mathrm{C}_{2}$

Fig. 4. Microstrucure of composite nickel alloy overlays strengthened by: a) $\mathrm{TiC}$, b) $\mathrm{Cr}_{3} \mathrm{C}_{2}$ stopniowo temperature podłoża. Na rysunku 1 pokazano widok z góry próbek po testach rozpływności, a w tablicy II wyniki pomiarów pola powierzchni rozpływu stopu Ni. Są to wartości średnie z dwóch niezależnych doświadczeń.

Otrzymane wyniki wskazują, że rozpływność stopu Ni na podłożu z TiC jest wyraźnie mniejsza niż na powierzchni $\mathrm{Cr}_{3} \mathrm{C}_{2}$, pomimo wyższej temperatury zakończenia procesu.

W wyniku oględzin makroskopowych stwierdzono, iż otrzymane powłoki mają poprawny wygląd bez istotnych wad geometrycznych kształtu i pęknięć. Jedynie napoiny $z$ dodatkiem TiC otrzymane przy małych wartościach natężenia prądu $(60 \div 70 \mathrm{~A})$ charakteryzowały się nieregularnym kształtem lica.

Badania mikroskopowe w powłokach umacnianych TiC wykonanych przy małym natężeniu prądu, tj. 60 , 70 i 80 A ujawniły niezgodności spawalnicze w postaci braku metalurgicznego połączenia warstwy z materiałem podłoża (rys. 2a). Powłoki kompozytowe umacniane $\mathrm{Cr}_{3} \mathrm{C}_{2}$ formowały się poprawnie $\mathrm{w}$ całym zakresie stosowanych parametrów (rys. 2b).

Badania mikroskopowe ujawniły różną morfologię węglików w osnowie napoin (rys. 3). W otrzymanych warstwach obserwowano różny kształt i wielkość cząstek umocnienia. Na rysunku 3a widoczne są duże, nieregularne cząstki TiC, a także znaczący udział drobnej frakcji tego węglika. Pojawienie się drobnych ziaren TiC $w$ osnowie jest spowodowane rozpadem dużych ziaren umocnienia pod wpływem oddziaływania łuku plazmowego bądź na skutek ich reakcji z ciekłą osnową $\mathrm{Ni}$. W napoinach umacnianych $\mathrm{Cr}_{3} \mathrm{C}_{2}$ obserwowano duże i nieregularne oraz mniejsze wydłużone cząstki fazy umacniającej (rys. 3b). Wydłużony kształt i usytuowanie sugerują krystalizację z przesyconego roztworu. Cząstki te tworzą charakterystyczne figury w kształcie gwiazdy.

Mikrostruktury powłok kompozytowych przy większym powiększeniu pokazano na rysunku 4 . W obu przypadkach granica międzyfazowa węglik-osnowa jest ciągła. W napoinach umacnianych TiC widoczna jest dezintegracja dużych cząstek węglika spowodowana penetracją ciekłej osnowy po granicach ziaren (rys. 4a). Obserwowano także dezintegrację warstwy powierzchniowej dużych cząstek TiC, wskutek której powstaje znaczna ilość drobnej frakcji węglika. Nie ujawniono natomiast warstwy przejściowej na granicy międzyfazowej TiC-osnowa. Inny charakter oddziaływania osnowy z fazą umacniającą obserwowano w napoinach umacnianych $\mathrm{Cr}_{3} \mathrm{C}_{2}$. Na rysunku $4 \mathrm{~b}$ widoczne są ciemne cząstki węglika na tle jasnej osnowy, a wokół nich sytuują się iglaste wydzielenia ciemniejszej fazy, zorientowane prostopadle do powierzchni macierzystej węglika (rys. 4b). Na granicy międzyfazowej węglik-osnowa wyraźnie widać strefę przejściową.

Równomierne rozmieszczenie cząstek fazy umacniającej w osnowie warunkuje powtarzalne właściwości eksploatacyjne napoin. Podjęto próbę ilościowej charakterystyki tego rozmieszczenia, wykorzystując 
różnicę intensywności kolorów ziaren węglików i osnowy napoin. Do tego celu zaadaptowano komputerowy program do analizy obrazów metalograficznych MultiScanBase. Badane obrazy mikroskopowe dzielono na równe obszary i dla każdego z nich wykonano histogram lokalny stopnia szarości oraz określano średnią jasność całego obrazu. Wobec znacznego kontrastu pomiędzy osnową i ziarnami węglików, rozkład jasności i średnia jasność obrazu mogą być miarą rozmieszczenia węglików w osnowie. W histogramie rzędna y pokazuje, ile jest obszarów o jasności wizualizowanej w postaci paska pod osią x. Na rysunkach 5 i 6 przedstawiono przykładowe wyniki obliczeń dla napoin

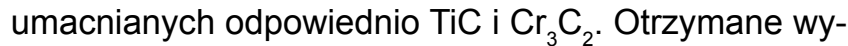
niki wskazują, iż rozmieszczenie cząstek fazy umacniającej w osnowie różni się znacznie w poszczególnych próbkach.

a)

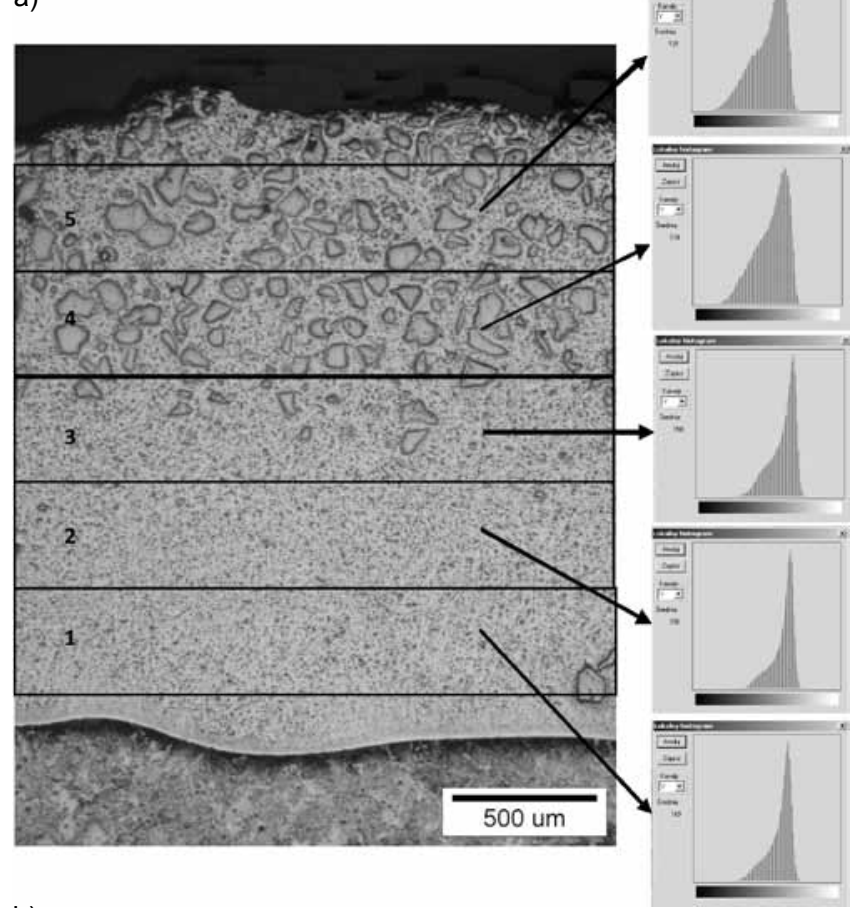

b)

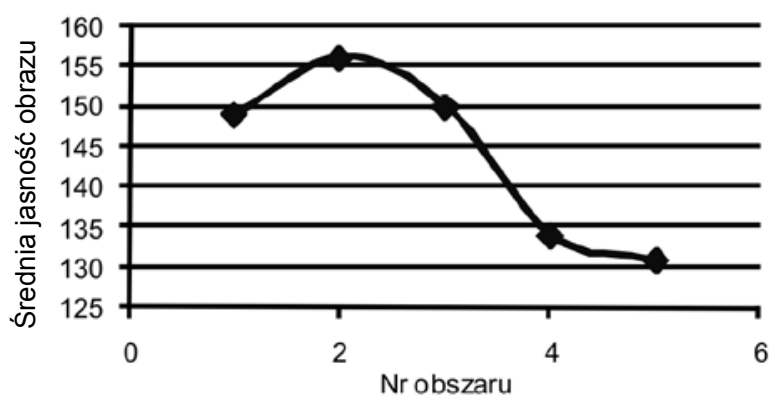

Rys. 5. Rozmieszczenie TiC w osnowie napoiny otrzymanej przy natężeniu prądu łuku plazmowego $90 \mathrm{~A}$ : a) histogramy rozkładu jasności punktów w zaznaczonych obszarach, b) średnia jasność obszarów funkcji odległości od linii wtopienia

Fig. 5. TiC particles distribution in the matrix in the overlay deposited by 90 A plasma arc current: a) bar charts of brightness in the marked areas; b) average brightness of areas as function of the distance from the fusion line
W powłokach umacnianych TiC cząstki fazy umacniającej lokują się głównie w obszarze bliskim licu napoiny, natomiast przy linii wtopienia jest ich znacznie mniej. Wobec tego na histogramach lokalnych widoczna jest rosnąca ilość obszarów o ciemniejszej barwie od linii wtopienia w kierunku lica powłoki (rys. 5a), a średnia jasność badanych obszarów obrazu zmniejsza się w kierunku lica (rys. 5b). W napoinach kompozytowych z $\mathrm{Cr}_{3} \mathrm{C}_{2}$ cząstki fazy umacniającej są jaśniejsze od osnowy, co oznacza że im większa jest ilość jasnych obszarów na histogramach lokalnych, tym udział węglików jest większy. W powłokach tych duże cząstki lokują się przy linii wtopienia, natomiast mniejsze występują przy licu warstwy, przy czym ich udział wzrasta (rys. 6a). W części środkowej napoiny dominują małe, jasne cząstki w kształcie igieł na tle ciemnej osnowy, toteż średnia jasność z tego obszaru jest najmniejsza (rys. 6b).

a)

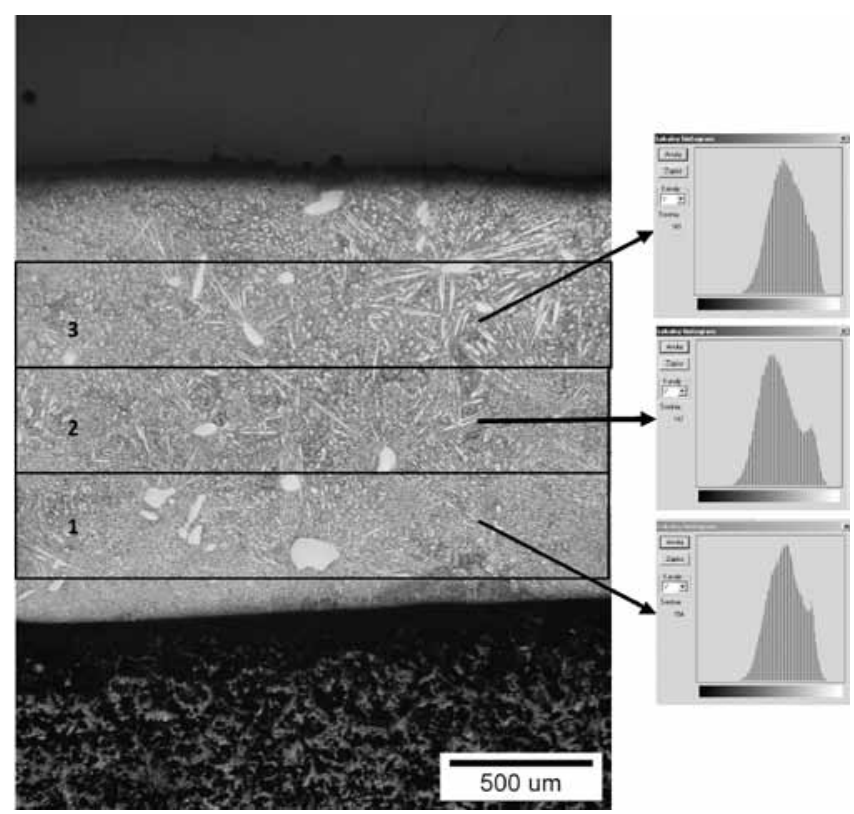

b)

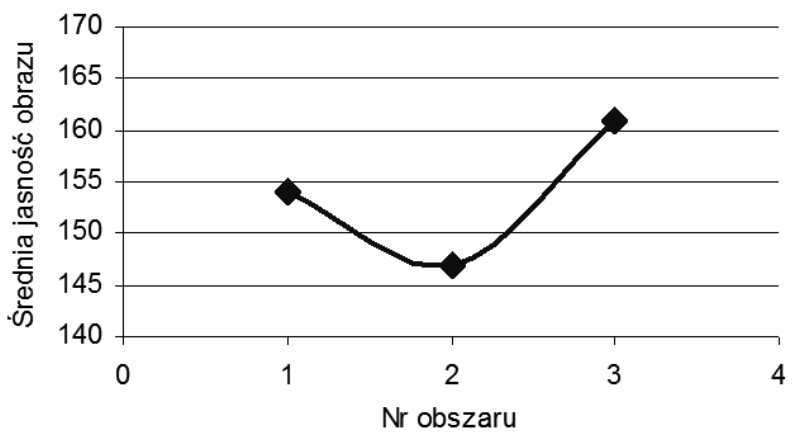

Rys. 6. Rozmieszczenie $\mathrm{Cr}_{3} \mathrm{C}_{2}$ w osnowie napoiny otrzymanej przy natężeniu prądu łuku plazmowego $90 \mathrm{~A}$ : a) histogramy rozkładu jasności punktów w zaznaczonych obszarach, b) zmiana średniej jasności w funkcji odległości od linii wtopienia

Fig. 6. $\mathrm{Cr}_{3} \mathrm{C}_{2}$ particles distribution in the overlay deposited by $90 \mathrm{~A}$ plasma arc current: a) brightness bar charts in the marked areas; b) average brightness of areas as function of the distance from the fusion line 


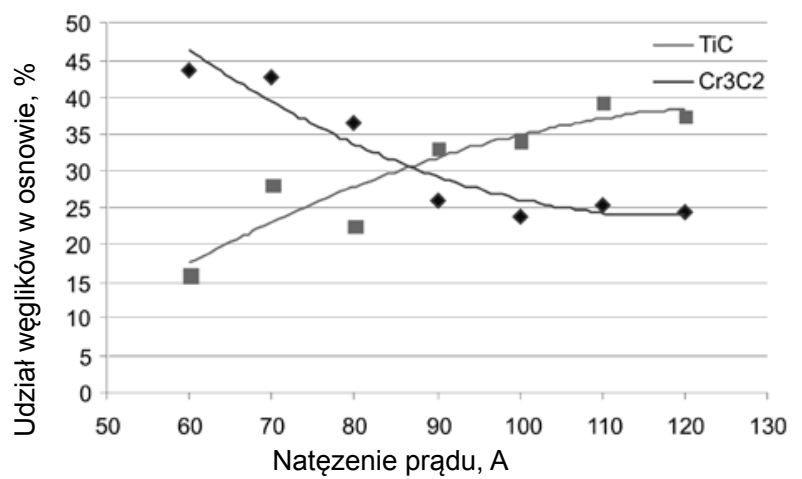

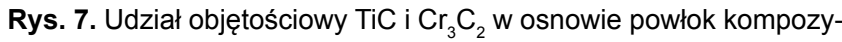
towych w funkcji prądu napawania

Fig. 7. $\mathrm{TiC}$ and $\mathrm{Cr}_{3} \mathrm{C}_{2}$ volume content in the matrix of composite overlays versus plasma arc current

Obliczenia udziału objętościowego cząstek fazy umacniającej w powłokach kompozytowych wykonano, stosując również program MultiScanBase. Korzystając z zasady Cavalieriego - Hacquerta, analizę prowadzono na przekrojach poprzecznych. Do badań przygotowano zdjęcia mikrostruktur $w$ formie binarnej, a obliczenia wykonano z całego pola powierzchni przekroju napoin. Otrzymane wyniki udziału fazy umacniającej w funkcji natężenia prądu napawania przedstawiono na rysunku 7.

$\mathrm{Na}$ podstawie uzyskanych wyników można ogólnie stwierdzić, iż udział objętościowy TiC zwiększa się wraz ze wzrostem natężenia prądu, natomiast $\mathrm{Cr}_{3} \mathrm{C}_{2}$ maleje.

\section{Dyskusja wyników badań}

$\mathrm{Na}$ podstawie przeprowadzonych badań można stwierdzić, że różny charakter i intensywność oddziaływania $\mathrm{TiC} \mathrm{i}_{\mathrm{Cr}_{3}} \mathrm{C}_{2}$ z osnową stopu Ni podczas procesu napawania plazmowego wpływa istotnie na formowanie się powłok kompozytowych, a następnie na rozmieszczenie i udział fazy umacniającej w osnowie. Istotną rolę odgrywają procesy oddziaływania międzyfazowego pomiędzy cieczą i fazą umacniającą, co dokumentują badania modelowe oraz aplikacyjne realnych napoin.

Badania modelowe wykazały, że rozpływność stopu na bazie Ni na podłożach $\mathrm{Cr}_{3} \mathrm{C}_{2}$ jest znacznie większa niż na TiC. Świadczy to także o lepszej zwilżalności $\mathrm{Cr}_{3} \mathrm{C}_{2}$ stopem Ni. Ponieważ lepsza zwilżalność wynika $z$ większego udziału wiązań metalicznych w węgliku, stąd wniosek, że udział wiązań metalicznych w węglikach metali przejściowych zwiększa się w grupach od IVB do VIB.

Badania aplikacyjne potwierdzają odmienny charakter oddziaływania ciekłego stopu Ni z węglikami tytanu i chromu. Z badań tych wynika, że warunkiem otrzymywania poprawnych napoin z udziałem TiC jest stosowanie odpowiednio wysokiego natężenia prądu napawania ( $\geq 90 \mathrm{~A}$ ), natomiast powłoki $z \mathrm{Cr}_{3} \mathrm{C}_{2}$ formowały się poprawnie w całym zakresie stosowanych parametrów. Słabsza zwilżalność cząstek TiC ciekłą osnową negatywnie wpływa na proces formowania się powłok i jest przyczyną powstawania niezgodności spawalniczych (rys. 2a). Wzrost natężenia prądu podnosi temperaturę ciekłego jeziorka oraz wydłuża czas kontaktu z ciekłą osnową, a to sprzyja lepszemu zwilżaniu cząstek fazy umacniającej. Toteż poprawne powłoki uzyskuje się, stosując większą energię liniową procesu.

Analiza granicy międzyfazowej węglik-osnowa wykazała, iż w TiC zachodziła penetracja ciekłej osnowy po granicach ziarn i wskutek tego dezintegracja dużych aglomeratów węglika na mniejsze cząstki (rys. 4a). Granica międzyfazowa węglik-osnowa jest ciągła bez wyraźnych stref przejściowych. W napoinach kompozytowych umacnianych $\mathrm{Cr}_{3} \mathrm{C}_{2}$ cząstki fazy umacniającej ulegały całkowitemu bądź częściowemu rozpuszczaniu i ponownie krystalizowały z przesyconego roztworu (rys. 4b). Wzdłuż ciągłej granicy międzyfazowej węglik-osnowa widoczna jest strefa przejściowa.

Charakter oraz intensywność oddziaływania węglików z ciekłą osnową jest podstawowym czynnikiem wpływającym na ich rozmieszczenie w napoinach kompozytowych. Gdy cząstki węglików są gorzej zwilżane, istnieje tendencja do wypierania ich z ciekłego jeziorka, gdy zwilżalność jest dobra wówczas są utrzymywane w cieczy. Wyniki badań wykazują, że rozmieszczenie węglików tytanu i chromu w osnowie napoin istotnie się różni. Cząstki TiC mają tendencję do lokowania się przy licu powłoki a w napoinach $\mathrm{z} \mathrm{Cr}_{3} \mathrm{C}_{2}$ duże cząstki lokują się przy linii wtopienia i strefie środkowej.

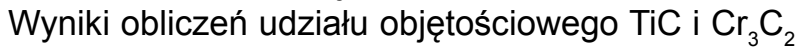
w osnowie powłok kompozytowych wykazują wyraźne różnice. Wraz ze wzrostem natężenia prądu udział TiC w osnowie napoin zwiększa się, mimo większego rozcieńczenia powłoki materiałem podłoża i zwiększenia objętości ciekłego jeziorka, podczas gdy w warstwach $\mathrm{z} \mathrm{Cr}_{3} \mathrm{C}_{2}$ zależność ta jest odwrotna. Można to wyjaśnić słabszym oddziaływaniem TiC z ciekłym stopem $\mathrm{Ni}$ (gorszą zwilżalnością), co początkowo utrudnia wprowadzenie go do ciekłej osnowy. Wzrost natężenia prądu poprzez aktywację cieplną procesu zwilżania powoduje zatrzymywanie coraz większej ilości cząstek TiC $w$ ciekłej osnowie, kompensując nawet wzrost jej objętości. Należy też pamiętać, iż węglik tytanu ma wyższą temperaturę topnienia $\mathrm{i}$ jest stabilniejszy termodynamicznie, a więc trwalszy w strumieniu plazmy, niż węglik chromu.

W powłokach kompozytowych z węglikiem chromu wzrost natężenia prądu skutkuje większym rozcieńczeniem napoiny materiałem podłoża oraz intensyfikuje proces rozpuszczania cząstek węglika, toteż całkowity udział $\mathrm{Cr}_{3} \mathrm{C}_{2}$ zmniejsza się. 


\section{Wnioski}

Węgliki tytanu i chromu wykazują oddziaływanie z cieczą metaliczną na bazie $\mathrm{Ni}$, przy czym intensywniejsze oddziaływanie, którego miarą może być rozpływność, występuje w układzie $\mathrm{Cr}_{3} \mathrm{C}_{2}$ - stop $\mathrm{Ni}$.

Metoda napawania plazmowego pozwala na otrzymywanie powłok kompozytowych o osnowie Ni umacnianych węglikami $\mathrm{Ti}$ i $\mathrm{Cr}$ z mieszaniny proszków na podłożu ze stali S355J0.

Podczas napawania cząstki węglika tytanu ulegają dezintegracji w wyniku penetracji cieczy po granicach ziarn, przez co powstaje znaczna ilość drobnej frakcji. Natomiast w powłokach z udziałem węglika chromu cząstki fazy umacniającej mają tendencję do rozpuszczania się w ciekłej osnowie. Podczas chłodzenia krystalizują nowe fazy z przesyconego roztworu.
$\mathrm{Na}$ granicy międzyfazowej TiC-osnowa $\mathrm{Ni}$ nie tworzą się warstwy przejściowe, w odróżnieniu od jej granic $z \mathrm{Cr}_{3} \mathrm{C}_{2}$.

W napoinach kompozytowych cząstki TiC mają tendencję do sytuowania się przy licu powłoki, natomiast rozmieszczenie $\mathrm{Cr}_{3} \mathrm{C}_{2}$ jest zbliżone do równomiernego.

Ze wzrostem natężenia prądu napawania udział objętościowy TiC w osnowie wzrasta pomimo większego nadtapiania materiału podłoża, w wyniku intensyfikacji oddziaływania z cieczą poprzez aktywację termiczną. Natomiast w powłokach z $\mathrm{Cr}_{3} \mathrm{C}_{2}$ udział cząstek fazy umacniającej zmniejsza się w miarę wzrostu energii liniowej, wskutek procesu ich rozpuszczania.

\section{Literatura}

[1] Liu Y. F., Xia Z. Y., Han J. M., Zhang G. L., Yang S. Z.: Microstructure and wear behavior of $(\mathrm{Cr}, \mathrm{Fe}) 7 \mathrm{C} 3$ reinforced composite coating produced by plasma transferred arc weId-surfacing process, Surface \& Coatings Technology, 2006 No. 201, 863-867.

[2] Ozel S., Kurt B., Somunkiran I., Orhan N.: Microstructural characteristic of NiTi coating on stainless steel by plasma transferred arc process, Surface \& Coatings Technology, 2008, No. 202, 3633-3637.

[3] Klimpel A.: Technologie napawania i natryskiwania cieplnego, Wyd. P. Śl., Gliwice 1999.

[4] Huang Z., Hou Q., Wang P.: Microstructure and properties of $\mathrm{Cr}_{3} \mathrm{C}_{2}$ - modified nickel - based alloy coating deposited by plasma transferred arc process, Surface \& Coatings Technology, 2008, No. 202, 2993-2999.

[5] Deuis R.L., Yellup J.M., Subramanian C.: Metal-matrix composite coatings by PTA surfacing. Composite Science \& Technology, 58, 1998, 299-309.

[6] Liu Y. F., Han J. M., Li R. H., Li W. J., Xu X. Y., Wang J. H., Yang S. Z.: Microstructure and dry-sliding wear resistance of PTA cald $(\mathrm{Cr}, \mathrm{Fe}) 7 \mathrm{C} 3 / \mathrm{Y}$ - Fe ceramal composite coating, Applied Surface Science, 2006, No. 252, 7539-7544.

[7] Liu Y. F., Mu J. S., Xu X. Y., Yang S. Z.: Microstructure and dry-sliding wear properties of TiC-reinforced composite coating prepared by plasma-transferred arc weld-surfacing process, Materials Science and Engineering A, 2007, No 458, 366-370.
[8] Aoh J. N., Jeng Y. R., Chu E. L., Wu L. T.: On the wear behavior of surface clad layers under high temperature, Wear, 1999, No 225 - 229, 1114-1122.

[9] Kim H. J., Yoon B. H., Lee Ch. H.: Sliding wear performance in molten $\mathrm{Zn}-\mathrm{Al}$ bath of cobalt-based overlayers produced by plasma-transferred arc weld-surfacing, Wear, 2003, No. $254,408-414$.

[10] Deuis R.L., Subramanian C., Yellup J. M.: Abrasive wear of composite coatings in a saline sand slurry environment, Wear, 1997, No. 203-204, 119-128.

[11] Hou Q. Y., He Y. Z., Zhang Q. A., Gao J. S.: Influence of molybdenum on the microstructure and wear resistance of nikckel - based alloy coating obtained by plasma transferred arc process, Materials and Design, 2007, No. 28, 1982-1987.

[12] Gurumoorthy K., Kamaraj M., Prasad Rao K., Sambasiva Rao A., Venugopal S.: Microstructural aspects of plasma transferred arc surfaced Ni-based hardfacing alloy, Materials Science and Engineering A, 2007, No. 456, 11-19.

[13] Wu J. B. C., Redman J. E.: Hardfacing with Cobalt and Nickel Alloys, Welding Journal, 1994, September, 63-68.

[14] Toth L. E.: Transition Metal Carbides and Nitrides, Academic Press, New York and London, 1971.

[15] Wendler B.G.: Wykorzystanie reakcyjnej odrdzeniowej dyfuzji węgla w procesach uszlachetniania powierzchni. Zesz. Nauk. PŁ Nr 873, Łódź, 2001.

[16] Oyama S. T.: The chemistry of transition metal carbides and nitrides, Balckie Academic \& Professional, Chapman \& Hall, London, 1996. 